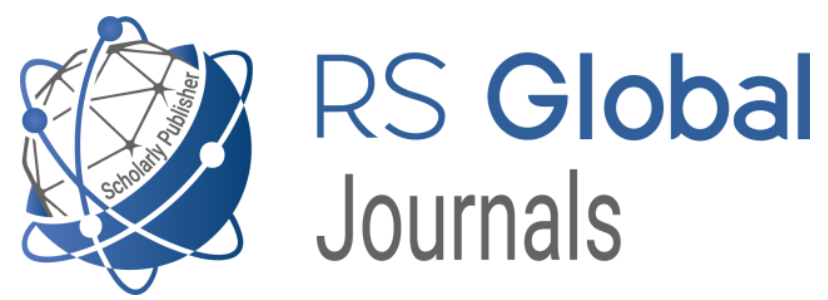

JOURNAL Science Review

p-ISSN 2544-9346

e-ISSN 2544-9443

PUBLISHER RS Global Sp. z O.O., Poland

$\begin{array}{ll}\text { ARTICLE TITLE } & \text { TRAINING, RE-TRAINING AND CERTIFICATION } \\ \text { TRAINING OF RESCUERS OF UKRAINE }\end{array}$

AUTHOR(S) Pokaliuk V. M., Fedorenko D. S.

ARTICLE INFO and Certification Training of Rescuers of Ukraine. Science Review. 7(34). doi: 10.31435/rsglobal_sr/31102020/7218

DOI https://doi.org/10.31435/rsglobal_sr/31102020/7218

RECEIVED 10 August 2020

ACCEPTED 04 October 2020

PUBLISHED $\quad 09$ October 2020

LICENSE

\section{(c) (i)}

This work is licensed under a Creative Commons Attribution 4.0 International License.

(C) The author(s) 2020. This publication is an open access article. 


\title{
TRAINING, RE-TRAINING AND CERTIFICATION TRAINING OF RESCUERS OF UKRAINE
}

\author{
Pokaliuk V. M., PhD in Pedagogical Sciences, Docent, Cherkasy Institute of Fire Safety named after \\ Chornobyl Heroes of National University of Civil Defence of Ukraine, Cherkasy, Ukraine, \\ ORCID ID: https://orcid.org/0000-0001-8706-7096, \\ Fedorenko D. S., PhD in Historical Sciences, Cherkasy Institute of Fire Safety named after \\ Chornobyl Heroes of National University of Civil Defence of Ukraine, Cherkasy, Ukraine, \\ ORCID ID: https://orcid.org/0000-0002-2069-7760
}

DOI: https://doi.org/10.31435/rsglobal_sr/31102020/7218

\section{ARTICLE INFO}

Received 10 August 2020

Accepted 04 October 2020

Published 09 October 2020

\section{KEYWORDS}

Professional training of rescuers,

professional (vocational)

education,

professional pre-higher

education,

higher education,

postgraduate education.

\begin{abstract}
The article reveals the content of the concepts of professional training, professional training of ordinary and senior staff. It is noted that the professional training of ordinary and managerial staff involves obtaining professional (vocational) higher, pre-higher, postgraduate education.

Professional training of newly appointed members of the rank and file and junior management may be carried out by obtaining professional (vocational) education in the relevant profession. Persons admitted to the civil defense service are sent to study in educational programs of professional (vocational) education after appointment.

Training of specialists with professional higher education is carried out in institutions of professional higher education of civil defense according to accredited educational and professional programs developed on the basis of standards of professional pre-higher education.

Professional training of ordinary and senior staff can be carried out by obtaining an educational degree at a certain level of higher education and the relevant specialty. Training of specialized specialists with higher education is carried out in institutions of higher education of civil defense, which provide training for accredited educational and professional (educational and scientific) programs developed on the basis of higher education standards.

Postgraduate education includes obtaining a second (next) higher education, advanced training, specialization, retraining and internship.

Taking into account the analysis of guiding documents and scientific literature, we found the need for conceptual justification and development of a system of professional training of rescuers, their preparation for successful activities during the service, firefighting, emergency response and their consequences.
\end{abstract}

Citation: Pokaliuk V. M., Fedorenko D. S. (2020) Training, Re-Training and Certification Training of Rescuers of Ukraine. Science Review. 7(34). doi: 10.31435/rsglobal_sr/31102020/7218

Copyright: (C) 2020 Pokaliuk V. M., Fedorenko D. S. This is an open-access article distributed under the terms of the Creative Commons Attribution License (CC BY). The use, distribution or reproduction in other forums is permitted, provided the original author(s) or licensor are credited and that the original publication in this journal is cited, in accordance with accepted academic practice. No use, distribution or reproduction is permitted which does not comply with these terms.

Introduction. During 2019, the bodies and formations of the State Emergency Service of Ukraine (SES) provided prompt response to 146 classified emergencies, which were distributed in such a way: state level -2 , regional level -7 , local level -63 , object level -74 . As a result, emergencies killed 199 people (including 23 children) and injured 1,492 people (including 624 children).

During 2019, 95,915 fires were recorded in settlements and facilities of business entities, which is $22 \%$ more than in 2018. As a result of fires, 1902 people died (including 58 children) and 1519 people were injured (including 135) [1]. 
Research in the field of training specialists to act in extreme conditions remains relevant due to the difficulty of finding patterns in these situations, as well as given the difficulties of systematizing actions in conditions of uncertainty, unpredictability, unexpectedness and ephemerality.

Materials and methods of research. Pedagogical aspects of the problem of professional training are revealed in the works N. Abashkina, R. Hurevych, I. Ziaziun, V. Kremen, A. Kuzminskyi, A. Lihotskyi, L. Lukianova, N. Nychkalo, L. Romanyshyna, M. Sysoieva, S. Smetanskyi, V. Yahupov and other scientists [2].

The process of professional training to perform professional actions under the influence of factors of extreme situations was studied by O. Aleksandrov, V. Ashmarin, A. Bolshakova, L. Hontarenko, O. Didenko, M. Diachenko，I. Zhdanov， L. Kandybovych， M. Koziar，O. Kokun, M. Korolchuk, D. Liebiediev, V. Lefterov, S. Myronets, V. Miroshnichenko, O. Okhremenko, V. Plisko, S. Poltorak, V. Sadkovyi, O. Sklen, O. Sobchenko, S. Yavorskyi and other scientists [2].

The process of professional training to perform professional actions under the influence of factors of extreme situations was studied by V. Arkhypenko, O. Bykova, V. But, V. Buzko, V. Varenyk, N. Vovchasta, V. Hora, L. Didukh, A. Demchenko, O. Diachkova, O. Ivashchenko, L. Ishychkina, M. Koval, I. Koval, M. Koziar, M. Kryshtal, M. Kusii, L. Mokhnar, Yu. Nenko, O. Parubok, K. Pasynchuk, O. Povstyn, V. Rotar, V. Solntsev, M. Severin, Yu. Taimasov, T. Tkachenko, O. Uzun, M. Shkarabura and other scientists [2].

Research methods: theoretical - analysis and synthesis of scientific data to substantiate the components of professional training of rescuers; empirical - observation, study of the results of rescuers.

Research results. Professional training - an organized, continuous and purposeful process of formation and development of rescuers' competencies necessary for professional activity in the profession (specialty) and successful performance of official duties in the relevant field, as well as their timely updating and improvement [3].

Professional training of ordinary and senior staff involves obtaining professional (vocational), professional higher, higher, postgraduate education [3].

Vocational training is carried out according to educational programs of professional (vocational and technical), professional higher, higher and postgraduate education in civil defense educational institutions (educational units) at the expense of budget funds allocated by the SES for these purposes and funds from other additional sources not prohibited by law.

By individual professions (groups of professions), specialties, professional training of ordinary and senior staff may be carried out in other educational institutions.

Persons who are admitted to the civil defense service for the positions of privates and junior officers for the first time and do not have a working profession, are sent for initial vocational training. Persons recruited to the Civil Defense Service for the positions of privates and junior officers who have previously (not more than 5 years before enrollment in the service) received professional (vocational) education in certain educational programs, are not sent for re-training in the same profession. They are allowed to perform their duties independently after completing their internship at the place of service.

Persons admitted to the civil defense service for the positions of privates and junior officers who have previously (more than 5 years before enrollment in the service) received professional (vocational) education in certain educational programs, are sent to a civil defense education institution (training unit) for advanced training in the same profession.

Ordinary and junior officers who are in the civil defense service and have the appropriate professional qualifications and who are planned to be transferred to a position with another professional qualification different from the previously obtained, before being appointed to a new position are sent to a civil defense education institution (training unit) for retraining.

During training in the system of vocational training it is prohibited to involve students in emergency rescue and other urgent work, professional and service activities, the implementation of which is associated with a risk to life and health, which can lead to injury or death because of their unprofessional actions.

Professional (vocational) education. Professional training of newly appointed privates and junior officers may be carried out by obtaining their professional (vocational) education in the relevant profession [3].

Persons admitted to the civil defense service are sent to study in educational programs of professional (vocational) education after appointment in accordance with the annual plans of professional training of civil defense bodies and units and plans-orders of SES. 
Persons who have completed the educational program of professional (vocational and technical) education and successfully passed the qualification certification are assigned the educational and qualification level "skilled worker" from the acquired profession of the relevant category, class (category).

For persons who have received professional (vocational) education, the heads of civil defense bodies and units organize an internship at the place of service under the guidance of a mentor.

According to the results of internships and tests by order of the head of the body or department of civil protection, graduates who have been trained in educational programs of professional (vocational) education, are allowed to perform their duties in the profession.

Professional higher education. Vocational training of ordinary and junior managers can be carried out by obtaining professional higher education in the relevant specialty [3].

Training of specialists with professional higher education is carried out in institutions of professional higher education of civil defense according to accredited educational and professional programs developed on the basis of standards of professional higher education.

Cadets who receive education under the educational and professional programs of professional higher education, undergo training practices in institutions of professional higher education of civil defense, as well as in the bodies and departments of civil defense, which have concluded a contract with them for service (training).

Cadets of institutions of professional higher education of civil defense based on the results of their successful implementation of the educational and professional program in the relevant specialty (specialization) are awarded the degree of professional higher education "professional junior bachelor".

Training of specialists with higher education. Professional training of privates and managers can be carried out by obtaining an educational degree at a certain level of higher education and the relevant specialty [3].

Training of specialized specialists with higher education is carried out in institutions of higher education of civil defense, which provide training for accredited educational and professional (educational and scientific) programs developed on the basis of higher education standards.

Training of other specialists with higher education for the needs of bodies and subdivisions of civil protection is carried out in higher education institutions subordinated to other central executive bodies.

Training of specialists from among the heads of the civil defense service at the third (educational and scientific) and scientific levels of education is carried out in post-graduate courses and doctoral studies of higher education institutions of civil defense.

The main types of practical training of cadets and students are educational practices.

Training practices are conducted in order to acquaint cadets and students of higher education institutions of civil defense with the specifics of the service in future specialties (specializations), obtaining primary management and professional skills.

The educational practice of cadets of final courses is the final stage of preparation of experts of the corresponding degree and qualification at a certain level of higher education and is spent after mastering of a theoretical part of the curriculum, before carrying out certification of cadets (listeners).

Applicants for higher education who have successfully completed the educational program are certified to establish compliance with the acquired knowledge, skills and other competencies to the requirements of higher education standards.

Postgraduate education. Professional training of rescuers can be carried out by obtaining postgraduate education, which involves the acquisition of new and improvement of previously acquired competencies on the basis of higher, professional (vocational) or professional higher education and practical experience [3].

Training is carried out in the system of postgraduate education:

members of the rank and file and junior officers of the civil defense service - in civil defense educational institutions (educational units);

persons of middle and senior management of bodies and divisions of civil defense - in institutions of higher education of civil defense or in other institutions of higher education, and persons of senior management also by participation in scientific and practical conferences, seminars, meetings, boards, etc.;

persons of the senior staff who belong to the categories of pedagogical, scientific-pedagogical and scientific staff in accordance with the legislation. 
Postgraduate education includes: obtaining a second (next) higher education, advanced training, specialization, retraining and internship.

Acquisition of the second (next) higher education by persons of secondary and senior management is a component of postgraduate education, which provides for obtaining a bachelor's degree (master's degree) in another specialty on the basis of higher education obtained not lower than a bachelor's degree.

Advanced training is a form of postgraduate education, which involves the acquisition by rescuers of new and / or improvement of previously acquired competencies within the professional activity or field of knowledge.

Advanced training is a form of postgraduate education, which involves the acquisition by rescuers of new and / or improvement of previously acquired competencies within the professional activity or field of knowledge.

After completing advanced training, rescuers - students of advanced training courses pass the appropriate exams and receive a certificate of advanced training of the established standard, which is attached to the personal file.

Specialization is a component of postgraduate education, which provides specialized training in order to acquire the middle and senior management of the civil protection service the ability to perform tasks and responsibilities that have certain features, within their existing specialty [3].

Persons of middle and senior management of civil defense bodies and subdivisions are subject to referral to civil defense educational institutions in case of their appointment (transfer) to another position (within a specialty, profession), performance of duties for which new (additional) knowledge, skills and abilities are required.

Specialization of persons of middle and senior management of bodies and divisions of civil protection is carried out in institutions of education of civil protection with separation from service. Terms of specialization for these people - up to 3 months.

The content of training in specialization courses in civil defense education institutions for each category of persons (by positions, specialties) is determined by educational programs, curricula, thematic plans developed by higher education institutions of civil defense and agreed in advance (before training) with relevant independent departments of SES.

Retraining is a component of postgraduate education, which involves professional training in order for rescuers to master in another profession on the basis of previously acquired profession and practical experience [3].

The content of retraining in civil defense educational institutions (educational units) for each profession is determined by the educational programs developed by these educational institutions (educational units) in accordance with the relevant educational standards.

Retraining is subject to persons of the rank and file and junior management, whose further performance of functional duties requires mastering another or additional profession.

Internship is the acquisition by rescuers of practical experience in performing professional tasks and responsibilities in a certain professional activity in the relevant positions [3].

Internships for privates and junior officers of civil defense bodies and units are conducted at the place of service.

Internships for middle, senior and senior management of civil defense bodies and units may be conducted at the place of service, and if necessary - in other bodies and units of civil protection and central executive bodies (by consent).

Discussion of results. Professional training is an organized, continuous and purposeful process of formation and development of rescuers' competencies necessary for professional activity in the profession (specialty) and successful performance of official duties in the relevant field, as well as their timely updating and improvement.

Professional training of ordinary and managerial staff provides for the acquisition of professional (vocational and technical), professional pre-higher, higher, postgraduate education.

Conclusions. Taking into account the analysis of guiding documents and scientific literature, we found the need for conceptual justification and development of a system of professional training of rescuers, their preparation for successful activities during the service, firefighting, liquidation of emergencies and their consequences. 


\section{REFERENCES}

1. Report on the main results of the State Emergency Service of Ukraine in 2019. Retrieved from https://www.kmu.gov.ua/storage/app/sites/1/17-civik-2018/zvit_2019/zvit-2019-dsns.pdf

2. Pokaliuk, V. (2020), "Practical training of personal of regular subdivisions of structural units of operative and rescue service of civil protection of Ukraine," World Science, 3 (55), 31-33. https://doi.org/10.31435/rsglobal_ws/31032020/6988

3. Order of the Ministry of Internal Affairs of Ukraine dated 26.05.2020 № 412 “On approval of the Procedure for training, retraining and advanced training of persons of the rank and file and senior staff of the civil defense service". Retrieved from https://zakon.rada.gov.ua/laws/show/z0496-20\#Text

4. Pokaliuk, V. M. (2020), "Training of personnel of operational calculations of rescue units in structural subdivisions of the Operational and Rescue Service of Civil Defense of Ukraine," International Journal of Innovative Technologies in Social Science, 2(23), https://doi.org/10.31435/rsglobal_ijitss/28022020/6947

5. Code of Civil Protection: Law of Ukraine from 02.10.2012 № 5403-VI. (2013), Information of the Supreme Council of Ukraine, 34-35, 458.

6. Kozyar, M. M. (2005). Theoretical and methodological bases of professional training of emergency department personnel. Vinnytsia.

7. Nyczkało, N., Kunikowski, J., \& Wierzbicki, G. (2018). Nauka, edukacja, wychowanie i praca: Księga jubileuszowa dedykowana Profesorowi doktorowi habilitowanemu Franciszkowi Szloskowi. WarszawaSiedlce. 